\title{
Perancangan Teknik Kriptografi Block Cipher Berbasis Pola Permainan Tradisional Rangku Alu
}

http://dx.doi.org/10.28932/jutisi.v5i2.1714

\author{
Perdana Bagas Tirta Kumbara ${ }^{\bowtie 1}$, Magdalena A. Ineke Pakereng *2 \\ ${ }^{1,2}$ Prodi Teknik Informatika, Fakultas Teknologi Informasi, Universitas Kristen Satya Wacana \\ Jl.Dr. O. Notohamidjojo, Salatiga 50714, Indonesia \\ ${ }^{1}$ kumbaraperdana@gmail.com \\ ${ }^{2}$ ineke.pakereng@uksw. edu
}

\begin{abstract}
Data security is one of the most important factors in the world of Information Technology today. One way to secure data is by Block Cipher Cryptography technique. However, some cryptographic techniques have been successfully solved by the cryptanalysis so that new cryptographic algorithms need to be created. The design of Cryptography algorithms based on traditional game patterns of Rangku Alu from East Nusa Tenggara is a design of Cryptographic Block Cipher algorithms that operate in the form of bits designed with 10 rounds where each cycle contains four processes. In each round, there are four patterns for the plaintext process and four patterns for the key. The fourth process is transformed with an S-Box table to get a more random ciphertext. Tests were also carried out using Avalance Effect which reached 49,38\% and the correlation value where there was a change in character reached $73,44 \%$. So the result designing Cryptographic algorithms can be used for encryption and description in text files.
\end{abstract}

Keywords-Cryptography, Block Cipher, S-BOX, Tarian Sajojo Papua Pattern, Correlation, Avalanche Effect.

\section{Pendahuluan}

Pengaruh teknologi informasi kini berperan hampir di setiap aspek kehidupan baik dalam pemerintahan, pendidikan, kesehatan, perbankan, bahkan dalam bidang militer sekalipun. Dengan semakin berkembangnya teknologi informasi, kini setiap orang dapat mengakses dan bertukar informasi atau data dengan mudah menggunakan internet baik yang bersifat publik maupun pribadi. Berkaitan dengan hal tersebut, tentunya tingkat keamanan data sangat diperlukan. Hal tersebut dilakukan agar data yang dikirimkan dapat sampai ke tujuan dengan aman serta guna mengantisipasi penyalahgunaan data oleh pihak yang tidak bertanggung jawab atau pihak yang tidak memiliki hak.

Oleh karena itu dikembangkan sebuah cabang ilmu yang mempelajari tentang keamanan informasi atau data yang disebut dengan Kriptografi. Kriptografi adalah ilmu yang mempelajari tentang teknik enkripsi data dimana data diacak dengan sebuah kunci sehingga menghasilkan data hasil enkripsi dan hanya dapat didekripsi oleh orang yang memiliki kunci dekripsi tersebut [1]. Namun dengan diterapkannya algoritma Kriptografi Block Cipher, bukan berarti hal tersebut merupakan jaminan sebuah data akan menjadi aman. Karena seiring dengan perkembangan teknologi, sudah banyak Algoritma Kriptografi Block Cipher yang sudah berhasil dipecahkan. Dengan demikian tentunya perlu dilakukan sebuah pengembangan algoritma baru agar polanya lebih sulit untuk dipecahkan.

Berdasarkan latar belakang masalah tersebut, maka dilakukan penelitian tentang perancangan Kriptografi menggunakan algoritma Block Cipher dengan memanfaatkan pola permainan tradisional Rangku Alu dari daerah Nusa Tenggara Timur (NTT) yang di dalamnya dikombinasikan dengan tabel S-Box. Rangku Alu merupakan permainan tradisional yang menggunakan bambu sebagai alat permainannya, Rangku Alu dapat dijadikan sebagai sarana edukasi dan pembentukan diri. Cara memainkannya adalah dengan membagi pemain menjadi dua kelompok, yaitu kelompok yang bermain dan kelompok yang menjaga. Kelompok yang menjaga menggerak-gerakkan bambu (empat orang berjongkok membentuk bidang persegi dan memegang dua bambu) sambil menyayi. Kelompok pemain yang mendapat giliran bermain akan melompat di sela-sela bambu. Mereka harus menghindari jepitan bambu. Penari akan masuk dalam bidang persegi dan melompat-lompat sesuai irama bukatutup bambu. Ketika bermain, bambu yang digerakkan menghasilkan irama yang berpola. Permainan tersebut dapat lebih menarik lagi dengan menyanyi bersama-sama mengikuti pola irama suara bambu [2]. Berdasarkan permainan Rangku Alu tersebut, pola pergerakan pemain dan pola pergerakan bambu diadopsi untuk diterapkan ke dalam perancangan Kriptografi. Pola permainan Rangku Alu dipilih karena memiliki keunikan dimana pergerakan polanya menyebar terstruktur. Pembuatan algoritma kriptografi baru dengan pola permainan Rangku Alu bertujuan untuk menciptakan suatu kriptografi block chiper yang baru, sehingga dapat membantu memperbaiki dan memperbarui kriptografi yang ada agar lebih bervariatif. 
Kriptografi berkembang dengan sedemikian rupa sehingga melahirkan bidang yang berlawanan yaitu kriptanalisis. Kriptanalisis adalah ilmu dan seni untuk memecahkan chipertext menjadi plainteks tanpa mengetahui kunci yang digunakan [3]. Dengan menggunakan kombinasi dari pergerakan pemain dan alat permainannya, menggabungkan dua hal yang ada dalam permainan tradisional Rangku Alu dapat membuat kriptanalis semakin sulit untuk memecahkan algoritma tersebut. Sehingga dengan digunakannya pola tersebut, dapat menghasilkan sebuah nilai korelasi dari pola yang digunakan dalam proses enkripsi dan dekripsi berdasarkan pesan asli atau plaintext yang ada.

\section{TINJAUAN PUSTAKA}

Penelitian yang pertama berjudul "Perancangan Kriptografi Block Cipher Berbasis pada Formasi Permainan Bola", penelitian ini membahas mengenai perancangan Kriptografi berbasis pada teknik formasi permainan bola yang dapat melakukan proses enkripsi dan dekripsi serta telah memenuhi 5-tuple dari Kriptosistem [4].

Penelitian yang kedua berjudul "Perancangan Kriptografi Block Cipher Berbasis Pola Formasi Futsal 1-2-1", penelitian ini membahas mengenai Kriptografi Block Cipher 256 bit berbasis formasi futsal 1-2-1 yang dapat menunjukkan ciri khas dari sebuah permainan futsal dalam sebuah tema sehingga dapat menyembunyikan kerahasiaan data dengan lebih baik [5].

Penelitian yang ketiga berjudul "Perancangan Kriptografi Block Cipher Berbasis Pola Gerakan Lempeng Tektonik Divergensi dan Konvergensi”, penelitian ini membahas mengenai perancangan kriptografi Block Cipher berbasis pada pola gerakan lempeng tektonik divergensi dan konvergensi dimana pola divergensi dijadikan dalam pertukaran kode bit pada plaintext, sedangkan pola konvergensi digunakan pada pertukaran kode bit kunci [6].

Penelitian yang keempat berjudul "Perancangan Kriptografi Block Cipher Berbasis Pola Ikan Berenang, penelitian ini membahas mengenai teknik Kriptografi dengan menggunakan pola ikan berenang" dimana merupakan pola yang unik. Dan apabila dilihat, ikan berenang memiliki pola yang menenangkan hati. Di sini jarang orang yang memperhatikan pola ini, maka akan sulit mengetahui dasar dari pola enkripsinya [7].

Penelitian yang kelima berjudul "Perancangan Kriptografi Block Cipher dengan Langkah Permainan Engklek", penelitian ini membahas mengenai eksperimen perancangan Block Cipher untuk diimplementasikan menjadi sebuah aplikasi yang dapat digunakan secara otomatis dengan melakukan enkripsi dan dekripsi. Pada penelitian ini juga menunjukkan bahwa permainan tradisional dari Indonesia dapat dijadikan dalam bentuk alur algoritma [8].

Berdasarkan penelitian-penelitian sebelumnya terkait perancangan Kriptografi Block Cipher, dengan tuntutan dewasa ini maka dilakukan penelitian tentang perancangan Block Cipher dengan memanfaatkan pola permainan tradisional Rangku Alu dari daerah Nusa Tenggara Timur (NTT). Diharapkan dengan menggunakan pola tersebut maka didapatkan pola yang lebih acak dengan mencari korelasi terbaik yang kemudian akan digunakan sebagai proses enkripsi dan dekripsi dari pesan plaintext.
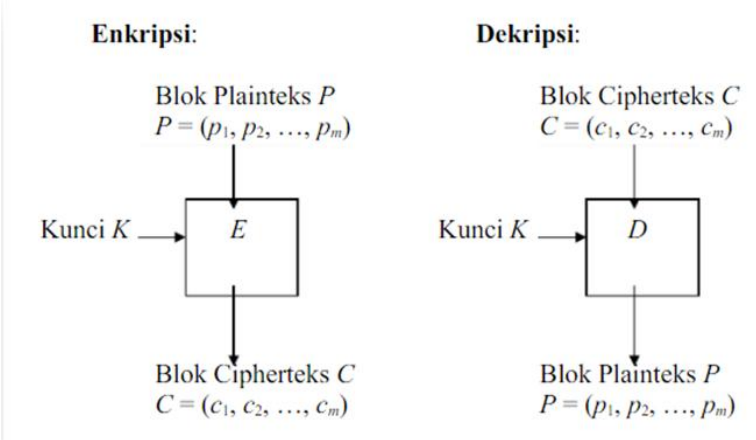

Gambar 1. Skema Proses Enkripsi dan Dekripsi pada Block Cipher [9]

Skema proses enkripsi dan dekripsi berdasarkan Gambar 1 dapat diuraikan seperti di bawah ini.

Block Plaintext (P) yang berukuran $\mathrm{m}$ bit dinyatakan sebagai :

$$
\mathrm{P}=\left(\mathrm{P}_{1}, \mathrm{P}_{2}, \ldots \mathrm{P}_{\mathrm{n}}\right)
$$

Block Ciphertext $(\mathrm{C})$ dinyatakan sebagai :

$$
\mathrm{C}=\left(\mathrm{C}_{1}, \mathrm{C}_{2}, \ldots \mathrm{C}_{\mathrm{n}}\right)
$$

Kunci / Key $(\mathrm{K})$ dinyatakan sebagai :

$$
\mathrm{K}=\left(\mathrm{K}_{1}, \mathrm{~K}_{2}, \ldots \mathrm{K}_{\mathrm{n}}\right)
$$

Proses enkripsi adalah :

$$
\mathrm{E}_{\mathrm{k}}(\mathrm{P})=\mathrm{C}
$$

Proses dekripsi adalah :

$$
\mathrm{D}_{\mathrm{k}}(\mathrm{C})=\mathrm{P}(\mathrm{C}) \mathrm{P}
$$

Syarat Kriptografi adalah dapat memenuhi lima-tupel (five-tuple) $\left(\mathrm{P}, \mathrm{C}, \mathrm{K}, \mathrm{E}_{\mathrm{k}}, \mathrm{D}_{\mathrm{k}}\right)$ dengan kondisi [10] :

1. $\mathrm{P}$ adalah himpunan berhingga dari plaintext. Pada rancangan Kriptografi ini menggunakan plaintext yang ekuivalen dengan karakter ASCII printable. Maka himpunan plaintext pada perancangan Kriptografi ini adalah himpunan berhingga.

2. $\mathrm{C}$ adalah himpunan berhingga dari ciphertext. Chipertext dihasilkan dalam elemen heksadesimal $(1,2, \ldots, 9, \mathrm{~A}, \ldots, \mathrm{F})$, maka himpunan chipertext yang dihasilkan merupakan elemen terbatas.

3. K Merupakan ruang kunci (Keyspace), adalah himpunan berhingga dari kunci.

4. Untuk setiap $\mathrm{k} \in \mathrm{K}$, maka ada $\mathrm{D}_{\mathrm{k}} \in \mathrm{E}$ dan berkorespondensi dengan aturan dekripsi $\mathrm{D}_{\mathrm{k}} \in \mathrm{D}$. Setiap $\mathrm{e}_{\mathrm{k}}: \mathrm{P} \rightarrow \mathrm{C}$ dan $\mathrm{d}_{\mathrm{k}}: \mathrm{C} \rightarrow \mathrm{P}$ adalah fungsi sedemikian hingga $\mathrm{d}_{\mathrm{k}}\left(\mathrm{e}_{\mathrm{k}}(\mathrm{x})\right)=\mathrm{x}$ untuk setiap plaintext $\mathrm{x} \in \mathrm{P}$. $\mathrm{E}=$ Enkripsi 


\section{$\mathrm{D}=$ Dekripsi}

Untuk mencapai hasil yang maksimum dari nilai yang acak, maka dalam pengujian ini menggunakan korelasi yang merupakan teknik statistik untuk mengukur kekuatan hubungan antara dua variabel dan untuk mengetahui bentuk hubungan antara dua variabel tersebut dengan hasil yang bersifat kuantitatif. Kekuatan hubungan antara dua variabel itu disebut dengan koefisien korelasi. Untuk mengetahui tingkat hubungan kuat atau lemahnya nilai korelasi, dapat menggunakan acuan dari Tabel I.

TABEL I

KLASIFIKASI KOEFISIEN KORELASI

\begin{tabular}{|l|l|}
\hline $\begin{array}{c}\text { Interval } \\
\text { Koefisian }\end{array}$ & \multicolumn{1}{c|}{$\begin{array}{c}\text { Tingkat } \\
\text { Hubungan }\end{array}$} \\
\hline $0,00-0,199$ & Sangat Rendah \\
\hline $0,20-0,399$ & Rendah \\
\hline $0,40-0,599$ & Sedang \\
\hline $0,60-0,799$ & Kuat \\
\hline $0,80-1,000$ & Sangat Kuat \\
\hline
\end{tabular}

Selain itu proses block cipher ini menggunakan operasi XOR dimana output yang dihasilkan dari proses enkripsi akan susah ditebak, karena apabila dilihat dasar dari XOR seperti berikut :

- $\quad 0$ XOR $0=0$

- $\quad 0$ XOR $1=1$

- 1 XOR $0=1$

- 1 XOR $1=0$

Maka apabila hasil output adalah 0 untuk mendapatkan inputnya kriptoanalis tidak tahu, bisa jadi input yang dihasilkan adalah 1 atau 0. Dasar tersebut digunakan untuk melakukan kriptografi block cipher.

Kemudian S-Box (Substitution Box) merupakan salah satu prinsip dalam perancangan block cipher dimana proses s-box itu sendiri adalah mengganti karakter inputan dengan karakter yang sudah menjadi ketetapan pada sebuah tabel dimana ditunjukkan pada Gambar 2.. Secara teoritis, S-Box adalah satu-satunya algoritma yang mempunyai kemampuan untuk membuat hubungan yang tidak linier antara plaintext dan ciphertext. Maka dari itu, penggunaan S-Box ditujukan agar membuat Kriptografi block cipher menjadi lebih acak. Hal ini dilakukan dengan cara mensubstitusikan bilangan hexadecimal ke dalam tabel S-Box dan kemudian ambil output dari tabel S-Box berupa bilangan hexadecimal yang baru.

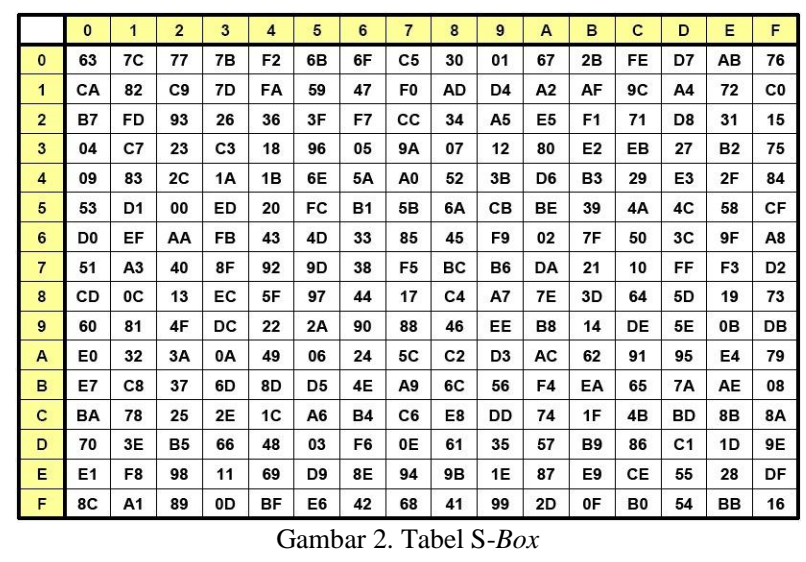

\section{METOde PeneliTIAN DAN PERANCANGAN SISTEM}

Dalam penelitian teknik perancangan Kriptografi dengan algoritma Block Cipher menggunakan pola permainan tradisional Rangku Alu dari Nusa Tenggara Timur (NTT) terdapat enam tahapan penelitian, yaitu : (1) Pengumpulan Bahan, (2) Analisis Masalah, (3) Studi Literatur, (4) Perancangan Kriptografi, (5) Uji Kriptografi, (6) Penulisan Laporan.

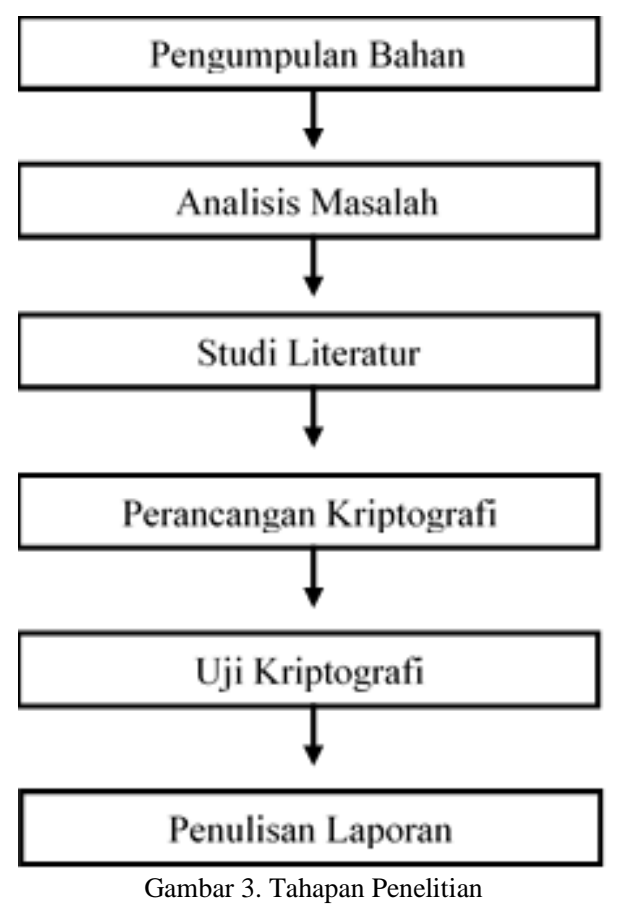

Tahap penelitian dari Gambar 3 dapat dijelaskan sebagai berikut : (1) Pengumpulan Bahan : yang menentukan pola untuk kriptografi baru dalam perancangan algoritma Kriptografi dengan pendekatan block cipher serta mengumpulkan referensi pendukung seperti artikel, cara bermain, video dari youtube, jurnal, (2) Analisa Masalah : tentang informasi keamanan menggunakan algoritma Kriptografi block cipher yang kemudian maksimal delapan karakter plaintext dan kunci,serta berapa bit yang digunakan, 
(3) Studi Literatur : dengan membaca berbagai sumber berkaitan dengan pola Kriptografi block cipher maka dapat di bandingkan dan mencari tingkat keacakan dari pola yang akan di buat, (4) Perancangan Kriptografi : Mulai melakukan perancangan Kriptografi block cipher 64-bit dengan pola permainan Rangku Alu, (5) Uji Kriptografi : setalah perancangan selesai kemudian dilakukan uji coba dari Kriptografi yang telah dibuat, pengujian meliputi hasil dari enkripsi dan dekripsi apakah sudah sesuai, serta mencari tau nilai Avalanche Effect, dan (6) Penulisan Laporan Penelitian : penulisan penelitian yang sudah dilakukan dalam bentuk laporan.

Dalam perancangan Kriptografi menggunakan algoritma Block Cipher pada pola permainan tradisional Rangku Alu ini dilakukan proses enkripsi dan proses dekripsi dimana dilakukan sebanyak 10 putaran. Masing-masing putaran terdiri dari proses empat pola.

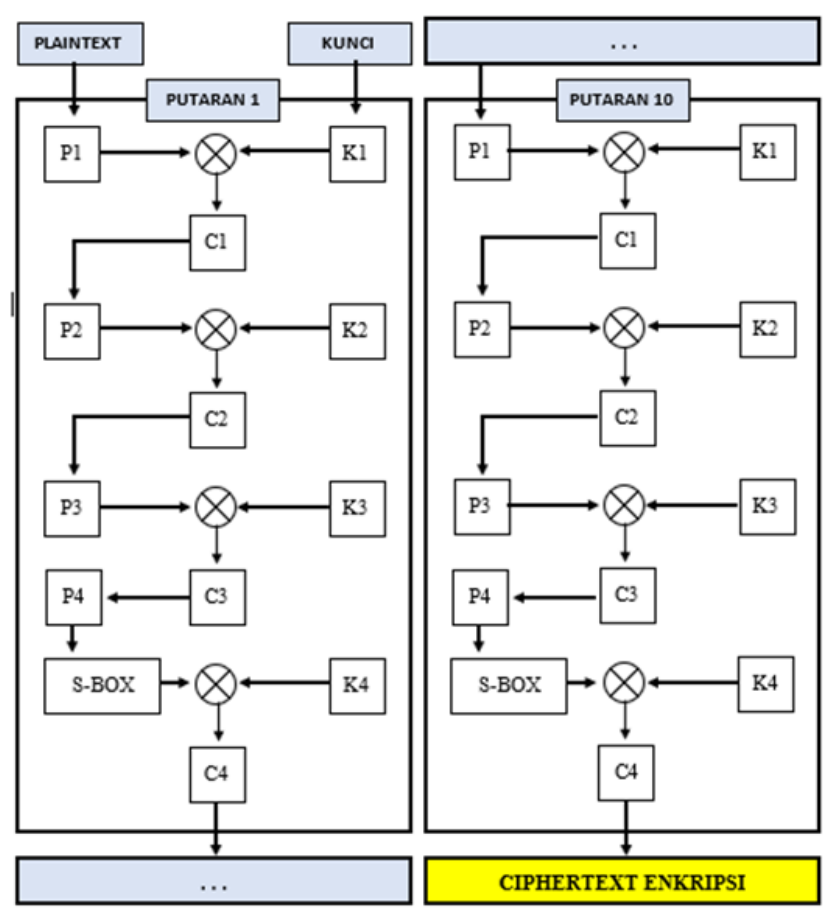

Gambar 4. Proses Enkripsi

Gambar 4 merupakan alur proses enkripsi. Tahapantahapan dari proses enkripsi dapat dijabarkan sebagai berikut : Menyiapkan plaintext dan kunci, kemudian plaintext dan kunci diubah menjadi biner sesuai tabel ASCII. Selanjutnya plaintext dan kunci akan melewati empat proses pada setiap putaran. Proses pertama yaitu plaintext 1 (P1) melakukan transformasi dengan pola permainan tradisional Rangku Alu dan dilakukan perhitungan XOR dengan kunci 1 (K1) yang kemudian menghasilkan ciphertext 1 (C1) dimana digunakan di proses selanjutnya sebagai plaintext 2 (P2). Proses selanjutnya adalah plaintext 2 (P2) melakukan transformasi dengan pola permainan tradisional Rangku Alu dan dilakukan perhitungan XOR dengan kunci 2 (K2) yang kemudian menghasilkan ciphertext 2 (C2) dimana digunakan di prosess selanjutnya sebagai plaintext 3 (P3). Langkah berikutnya adalah plaintext 3 (P3) melakukan transformasi dengan pola permainan tradisional Rangku Alu dan dilakukan proses perhitungan XOR dengan kunci 3 (K3) yang kemudian menghasilkan ciphertext 3 (C3) dimana digunakan di proses selanjutnya sebagai plaintext 4 (P4). Lalu plaintext $4(\mathrm{P} 4)$ melakukan transformasi dengan pola permainan tradisional Rangku Alu kemudian dilakukan proses S-Box dan dilakukan perhitungan XOR dengan kunci 4 (K4) yang kemudian menghasilkan ciphertext 4 (C4). Setelah mendapatkan ciphertext 4 (C4) maka akan digunakan pada putaran kedua dengan alur proses yang sama dengan putaran pertama. Tahap tersebut akan berlanjut sampai putaran ke-10 dimana pada putaran tersebut memberikan hasil ciphertext enkripsi.

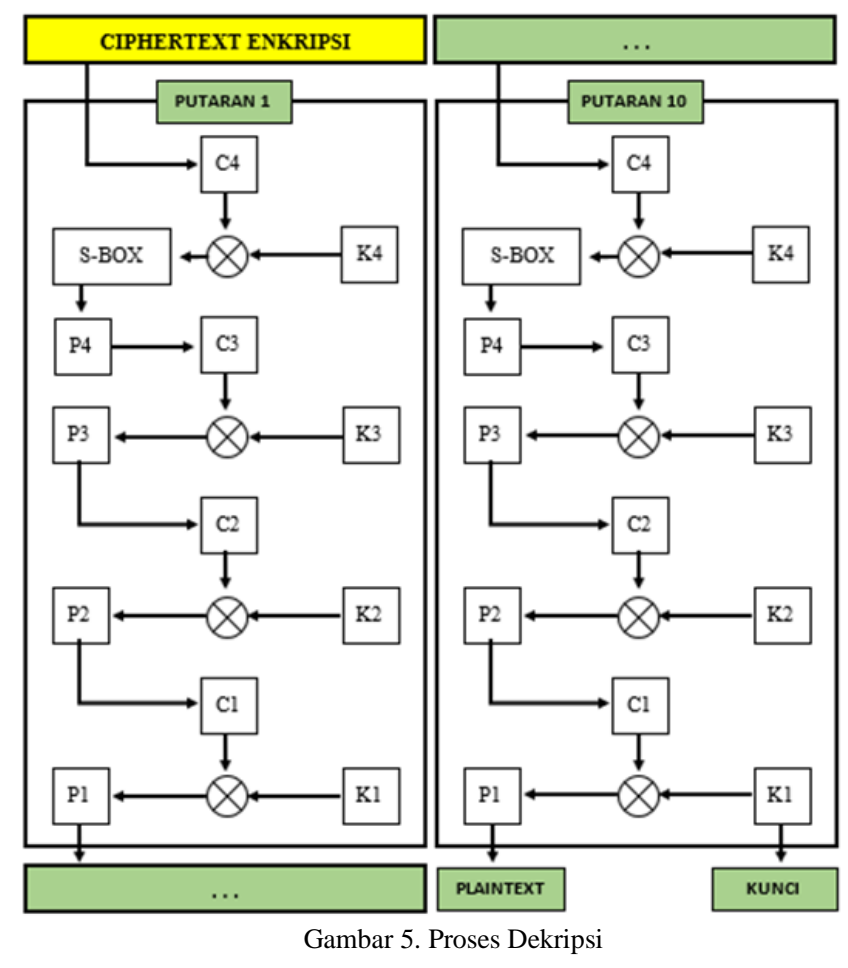

Gambar 5 merupakan alur proses dekripsi. Tahapantahapan dari proses dekripsi dapat dijabarkan sebagai berikut : Menyiapkan ciphertext dan kunci dari proses enkripsi putaran ke-10. Kemudian plaintext dan kunci akan melewati empat proses pada setiap putaran. Proses pertama yaitu ciphertext 4 (C4) diisi oleh ciphertext dari enkripsi putaran ke-10. Kemudian dilakukan perhitungan XOR dengan kunci 4 (K4) kemudian hasilnya akan dilakukan proses S-Box untuk menghasilkan plaintext $4(\mathrm{P} 4)$ dimana digunakan di proses selanjutnya sebagai ciphertext 3 (C3) untuk kemudian diproses dengan menggunakan pola dan dilakukan perhitungan XOR dengan kunci 3 (K3) dan menghasilkan plaintext 3 (P3) dimana digunakan di proses selanjutnya sebagai ciphertext 2 (C2) untuk kemudian 
diproses dengan menggunakan pola dan dilakukan proses perhitungan XOR dengan kunci 3 (K2) dan menghasilkan plaintext 2 (P2) dimana digunakan di proses selanjutnya sebagai ciphertext 1 (C1) untuk kemudian diproses dengan menggunakan pola dan dilakukan perhitungan XOR dengan kunci 1 (K1) dan menghasilkan plaintext 1 (P1). Tahap tersebut berlanjut sampai putaran 10 dan menghasilkan plaintext hasil dekripsi.

\section{IV.HASIL DAN PEMBAHASAN}

Dalam algoritma ini, pola yang diambil berasal dari permainan tradisional Rangku Alu yang kemudian digunakan sebagai proses pengambilan bit. Berikut adalah empat pola yang akan digunakan.
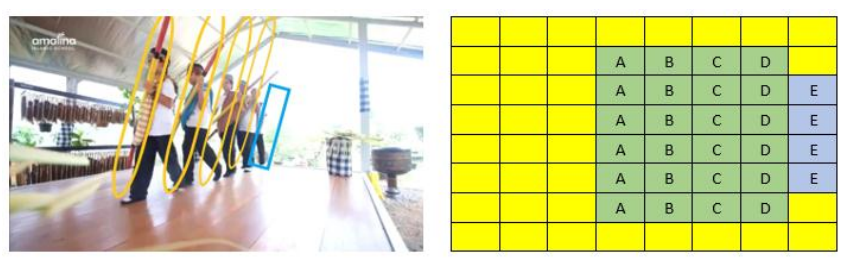

Gambar 6. Pola A dari Permainan Tradisional Rangku Alu

Pada Gambar 6 menunjukkan sebuah formasi awal dari permainan tradisional Rangku Alu, formasi ini digunakan untuk membuat Pola A dengan cara mengambil dari posisi tongkat bambu (tanda lingkaran orange) dan penarinya (tanda kotak biru). Setelah memberi tanda dan melihat formasinya, langkah berikutnya melakukan pemetaan posisinya dalam Pola A.
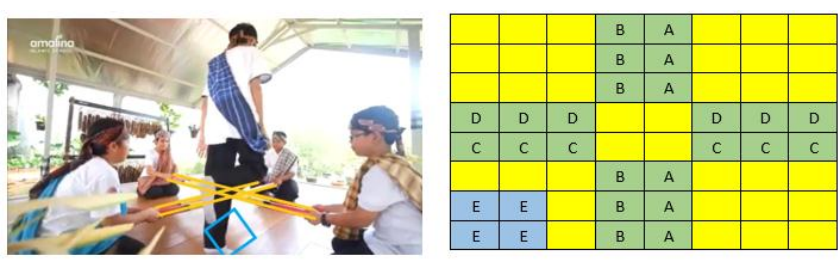

Gambar 7. Pola B dari Permainan Tradisional Rangku Alu

Pada Gambar 7 menunjukkan sebuah formasi dimana permainan mulai siap dimainkan, formasi ini yang akan digunakan untuk membuat Pola B dan caranya sama seperti cara menggambil Pola A yang berdasarkan posisi tongkat bambu dan posisi penarinya.
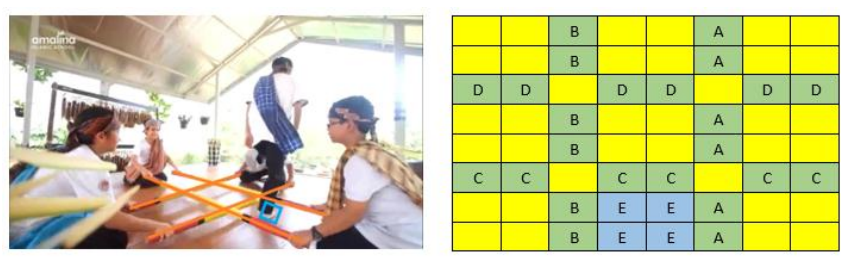

Gambar 8. Pola C dari Permainan Tradisional Rangku Alu
Pada gambar 8 menunjukkan posisi bambu menjadi terbuka dan pemain melompat ke posisi di antara dua bambu. Dari proses tersebut maka dapat dilakukan pemetaan yang menghasilkan $\mathrm{C}$.
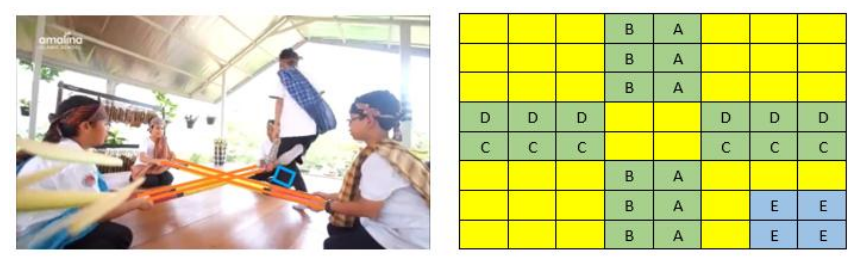

Gambar 9. Pola D dari Permainan Tradisional Rangku Alu

Pada Gambar 9 menunjukkan adanya perubahan posisi bambu kembali saling berdekatan dan pemain melompat keujung yang satunya. Dari proses tersebut maka dap dilakukan pemetaan yang menghasilkan Pola $\mathrm{D}$

Gambar 6, Gambar 7, Gambar 8, dan Gambar 9 masingmasing menunjukkan empat pola yang berbeda dimana masing-masing pola diambil merupakan pola yang berasal dari pola permainan tradisional Rangku Alu. Berdasarkan pola tersebut, dilakukanlah pengujian korelasi dengan mengkombinasikan urutan pola tersebut yang bertujuan untuk menemukan nilai korelasi terbaik. Pengujian yang dilakukan menggunakan contoh plaintext yaitu "DIESUKSW" dan kunci yaitu "BUDAYAKU".

Berdasarkan hasil pengujian korelasi, maka hasil terbaiklah yang akan digunakan sebagai acuan perancangan dalam proses enkripsi dan dekripsi.

TABEL II

RATA-RATA NILAI KORELASI

\begin{tabular}{|l|c|c|c|}
\hline POLA & NILAI & POLA & NILAI \\
\hline ABCD & 0.1739066 & CABD & 0.316055506 \\
\hline ABDC & 0.503568289 & CADB & 0.202153318 \\
\hline ACBD & 0.011053989 & CBAD & 0.504687923 \\
\hline ACDB & 0.097015629 & CBDA & 0.076848471 \\
\hline ADBC & 0.337461274 & CDAB & 0.242745957 \\
\hline ADCB & 0.749254038 & CDBA & 0.451843594 \\
\hline BACD & 0.272551791 & DABC & 0.12415066 \\
\hline BADC & 0.300657006 & DACB & 0.042473019 \\
\hline BCAD & 0.670632353 & DBAC & 0.322277928 \\
\hline BCDA & 0.1839073 & DBCA & 0.134645077 \\
\hline BDAC & 0.587720191 & DCAB & 0.284338932 \\
\hline BDCA & 0.445050163 & DCBA & 0.232420937 \\
\hline
\end{tabular}

Tabel II menujukkan hasil korelasi terbaik dari kombinasi pola yang digunakan. Dimana nilai terbaiknya terdapat pada pola ACBD,yang di dapat dari proses satu kali putaran pada masing-masing kombinasi. Kombinasi inilah yang akan digunakan untuk melanjutkan proses enkripsi hingga putaran ke-10 untuk menghasilkan ciphertext. 


\begin{tabular}{|c|c|c|c|c|c|c|c|}
\hline 1 & 16 & 17 & 32 & 64 & 49 & 48 & 33 \\
\hline 2 & 15 & 18 & 31 & 63 & 50 & 47 & 34 \\
\hline 3 & 14 & 19 & 30 & 62 & 51 & 46 & 35 \\
\hline 4 & 13 & 20 & 29 & 61 & 52 & 45 & 36 \\
\hline 5 & 12 & 21 & 28 & 60 & 53 & 44 & 37 \\
\hline 6 & 11 & 22 & 27 & 59 & 54 & 43 & 38 \\
\hline 7 & 10 & 23 & 26 & 58 & 55 & 42 & 39 \\
\hline 8 & 9 & 24 & 25 & 57 & 56 & 41 & 40 \\
\hline \multicolumn{7}{|c|}{ Gambar 10. Pola Ambil Kunci A }
\end{tabular}

\begin{tabular}{|c|c|c|c|c|c|c|c|}
\hline 57 & 58 & 59 & 60 & 61 & 62 & 63 & 64 \\
\hline 56 & 55 & 54 & 53 & 52 & 51 & 50 & 49 \\
\hline 41 & 42 & 43 & 44 & 45 & 46 & 47 & 48 \\
\hline 40 & 39 & 38 & 37 & 36 & 35 & 34 & 33 \\
\hline 25 & 26 & 27 & 28 & 29 & 30 & 31 & 32 \\
\hline 24 & 23 & 22 & 21 & 20 & 19 & 18 & 17 \\
\hline 9 & 10 & 11 & 12 & 13 & 14 & 15 & 16 \\
\hline 8 & 7 & 6 & 5 & 4 & 3 & 2 & 1 \\
\hline
\end{tabular}

Gambar 11. Pola Pemasukan Kunci A

\begin{tabular}{|c|c|c|c|c|c|c|c|}
\hline 1 & 16 & 64 & 49 & 17 & 32 & 48 & 33 \\
\hline 2 & 15 & 63 & 50 & 18 & 31 & 47 & 34 \\
\hline 3 & 14 & 62 & 51 & 19 & 30 & 46 & 35 \\
\hline 4 & 13 & 61 & 52 & 20 & 29 & 45 & 36 \\
\hline 5 & 12 & 60 & 53 & 21 & 28 & 44 & 37 \\
\hline 6 & 11 & 59 & 54 & 22 & 27 & 43 & 38 \\
\hline 7 & 10 & 58 & 55 & 23 & 26 & 42 & 39 \\
\hline 8 & 9 & 57 & 56 & 24 & 25 & 41 & 40 \\
\hline
\end{tabular}

\begin{tabular}{|c|c|c|c|c|c|c|c|}
\hline 64 & 63 & 62 & 61 & 60 & 59 & 58 & 57 \\
\hline 49 & 50 & 51 & 52 & 53 & 54 & 55 & 56 \\
\hline 48 & 47 & 46 & 45 & 44 & 43 & 42 & 41 \\
\hline 33 & 34 & 35 & 36 & 37 & 38 & 39 & 40 \\
\hline 32 & 31 & 30 & 29 & 28 & 27 & 26 & 25 \\
\hline 17 & 18 & 19 & 20 & 21 & 22 & 23 & 24 \\
\hline 16 & 15 & 14 & 13 & 12 & 11 & 10 & 9 \\
\hline 1 & 2 & 3 & 4 & 5 & 6 & 7 & 8 \\
\hline
\end{tabular}

Gambar 13. Pola Pemasukan Kunci B

\begin{tabular}{|c|c|c|c|c|c|c|c|}
\hline 40 & 39 & 38 & 37 & 36 & 35 & 34 & 33 \\
\hline 41 & 42 & 43 & 44 & 45 & 46 & 47 & 48 \\
\hline 56 & 55 & 54 & 53 & 52 & 51 & 50 & 49 \\
\hline 57 & 58 & 59 & 60 & 61 & 62 & 63 & 64 \\
\hline 25 & 26 & 27 & 28 & 29 & 30 & 31 & 32 \\
\hline 24 & 23 & 22 & 21 & 20 & 19 & 18 & 17 \\
\hline 9 & 10 & 11 & 12 & 13 & 14 & 15 & 16 \\
\hline 8 & 7 & 6 & 5 & 4 & 3 & 2 & 1 \\
\hline \multicolumn{7}{|c|}{ Gambar 14. Pola Ambil Kunci C } \\
\hline
\end{tabular}

\begin{tabular}{|c|c|c|c|c|c|c|c|}
\hline 8 & 9 & 24 & 25 & 40 & 41 & 56 & 57 \\
\hline 7 & 10 & 23 & 26 & 39 & 42 & 55 & 58 \\
\hline 6 & 11 & 22 & 27 & 38 & 43 & 54 & 59 \\
\hline 5 & 12 & 21 & 28 & 37 & 44 & 53 & 60 \\
\hline 4 & 13 & 20 & 29 & 36 & 45 & 52 & 61 \\
\hline 3 & 14 & 19 & 30 & 35 & 46 & 51 & 62 \\
\hline 2 & 15 & 18 & 31 & 34 & 47 & 50 & 63 \\
\hline 1 & 16 & 17 & 32 & 33 & 48 & 49 & 64 \\
\hline
\end{tabular}

Gambar 15. Pola Pemasukan Kunci C

\begin{tabular}{|c|c|c|c|c|c|c|c|}
\hline 40 & 39 & 38 & 37 & 36 & 35 & 34 & 33 \\
\hline 41 & 42 & 43 & 44 & 45 & 46 & 47 & 48 \\
\hline 25 & 26 & 27 & 28 & 29 & 30 & 31 & 32 \\
\hline 24 & 23 & 22 & 21 & 20 & 19 & 18 & 17 \\
\hline 56 & 55 & 54 & 53 & 52 & 51 & 50 & 49 \\
\hline 57 & 58 & 59 & 60 & 61 & 62 & 63 & 64 \\
\hline 9 & 10 & 11 & 12 & 13 & 14 & 15 & 16 \\
\hline 8 & 7 & 6 & 5 & 4 & 3 & 2 & 1 \\
\hline \multicolumn{6}{|c|}{ Gambar 16. Pola Ambil Kunci D } \\
\hline
\end{tabular}

\begin{tabular}{|c|c|c|c|c|c|c|c|}
\hline 1 & 16 & 17 & 32 & 33 & 48 & 49 & 64 \\
\hline 2 & 15 & 18 & 31 & 34 & 47 & 50 & 63 \\
\hline 3 & 14 & 19 & 30 & 35 & 46 & 51 & 62 \\
\hline 4 & 13 & 20 & 29 & 36 & 45 & 52 & 61 \\
\hline 5 & 12 & 21 & 28 & 37 & 44 & 53 & 60 \\
\hline 6 & 11 & 22 & 27 & 38 & 43 & 54 & 59 \\
\hline 7 & 10 & 23 & 26 & 39 & 42 & 55 & 58 \\
\hline 8 & 9 & 24 & 25 & 40 & 41 & 56 & 57 \\
\hline
\end{tabular}

Gambar 17. Pola Pemasukan Kunci D

Untuk Gambar 10, Gambar 12, Gambar 14, dan Gambar 16 merupakan pola dari kunci dimana nanti akan digunakan untuk mengambil data kunci yang tersedia. Sedangkan untuk Gambar 11, Gambar 13, Gambar 15, dan Gambar 17 berfungsi menyediakan bit untuk pengaplikasian perhitungan XOR dimana mengambil data dari kunci yang 
sudah memiliki pola seperti pada Gambar 10, Gambar 12, Gambar 14, dan Gambar 16.
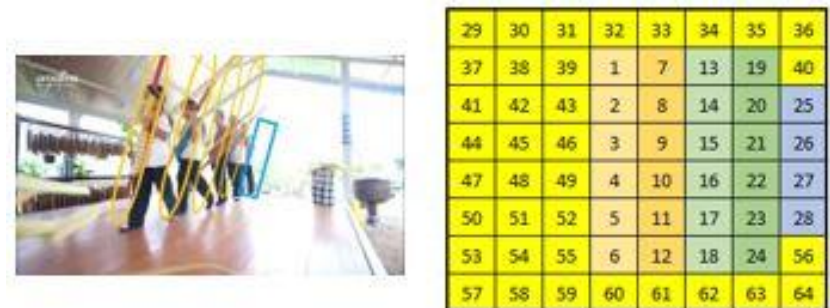

Gambar 18. Contoh Pengambilan Pola A

\begin{tabular}{|c|c|c|c|c|c|c|c|}
\hline 8 & 7 & 6 & 5 & 4 & 3 & 2 & 1 \\
\hline 9 & 10 & 11 & 12 & 13 & 14 & 15 & 16 \\
\hline 24 & 23 & 22 & 21 & 20 & 19 & 18 & 17 \\
\hline 25 & 26 & 27 & 28 & 29 & 30 & 31 & 32 \\
\hline 40 & 39 & 38 & 37 & 36 & 35 & 34 & 33 \\
\hline 41 & 42 & 43 & 44 & 45 & 46 & 47 & 48 \\
\hline 56 & 55 & 54 & 53 & 52 & 51 & 50 & 49 \\
\hline 57 & 58 & 59 & 60 & 61 & 62 & 63 & 64 \\
\hline
\end{tabular}

Gambar 19. Pola Pemasukan Plaintext

Gambar 18 dari permainan Rangku Alu dilihat dari atas formasi antara bambu dan penarinya digunakan untuk memasukkan ke dalam setiap blok setiap 8 bit dari karakter plainteks kedalam pola A dengan menggunakan Microsoft Excel. Kemudian pola yang sudah diberi angka tersebut mengambil data bit dari pola pemasukan plaintext sesuai Gambar 19.
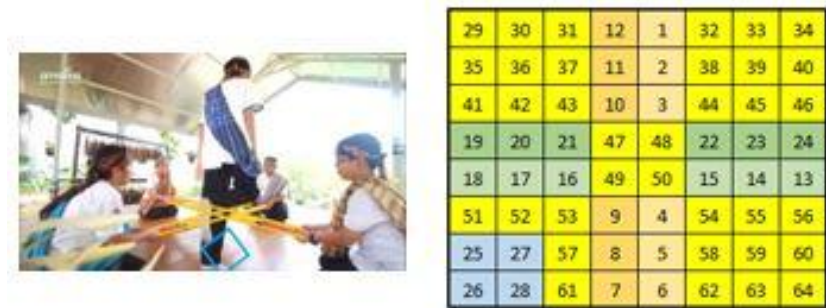

Gambar 20. Contoh Pengambilan Pola B

\begin{tabular}{|c|c|c|c|c|c|c|c|}
\hline 1 & 2 & 3 & 4 & 5 & 6 & 7 & 8 \\
\hline 16 & 15 & 14 & 13 & 12 & 11 & 10 & 9 \\
\hline 17 & 18 & 19 & 20 & 21 & 22 & 23 & 24 \\
\hline 32 & 31 & 30 & 29 & 28 & 27 & 26 & 25 \\
\hline 33 & 34 & 35 & 36 & 37 & 38 & 39 & 40 \\
\hline 48 & 47 & 46 & 45 & 44 & 43 & 42 & 41 \\
\hline 49 & 50 & 51 & 52 & 53 & 54 & 55 & 56 \\
\hline 64 & 63 & 62 & 61 & 60 & 59 & 58 & 57 \\
\hline 6
\end{tabular}

Gambar 20 dari permainan Rangku Alu dilihat dari atas formasi antara bambu dan penarinya digunakan untuk memasukkan ke dalam setiap blok setiap 8 bit dari karakter plainteks kedalam pola B dengan menggunakan Microsoft Excel. Kemudian pola yang sudah diberi angka tersebut mengambil data bit dari pola pemasukan plaintext sesuai Gambar 21.

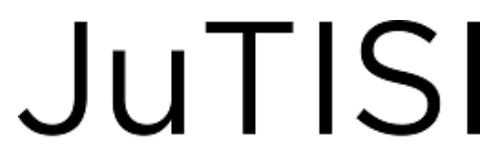

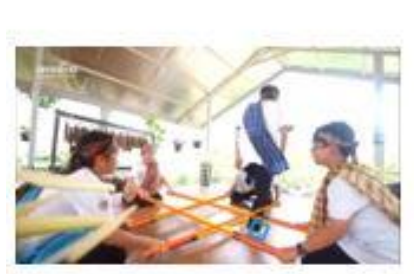

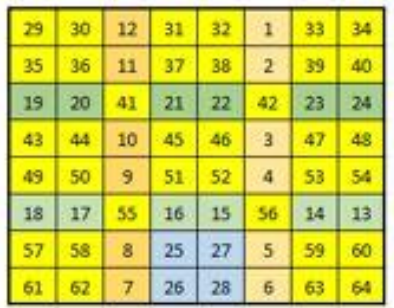

Gambar 22. Contoh Pengambilan Pola C

\begin{tabular}{|c|c|c|c|c|c|c|c|}
\hline 57 & 56 & 41 & 40 & 25 & 24 & 9 & 8 \\
\hline 58 & 55 & 42 & 39 & 26 & 23 & 10 & 7 \\
\hline 59 & 54 & 43 & 38 & 27 & 22 & 11 & 6 \\
\hline 60 & 53 & 44 & 37 & 28 & 21 & 12 & 5 \\
\hline 61 & 52 & 45 & 36 & 29 & 20 & 13 & 4 \\
\hline 62 & 51 & 46 & 35 & 30 & 19 & 14 & 3 \\
\hline 63 & 50 & 47 & 34 & 31 & 18 & 15 & 2 \\
\hline 64 & 49 & 48 & 33 & 32 & 17 & 16 & 1 \\
\hline 6
\end{tabular}

Gambar 22 dari permainan Rangku Alu dilihat dari atas formasi antara bambu dan penarinya digunakan untuk memasukkan ke dalam setiap blok setiap 8 bit dari karakter plainteks kedalam pola A dengan menggunakan Microsoft Excel. Kemudian pola yang sudah diberi angka tersebut mengambil data bit dari pola pemasukan plaintext sesuai Gambar 23.
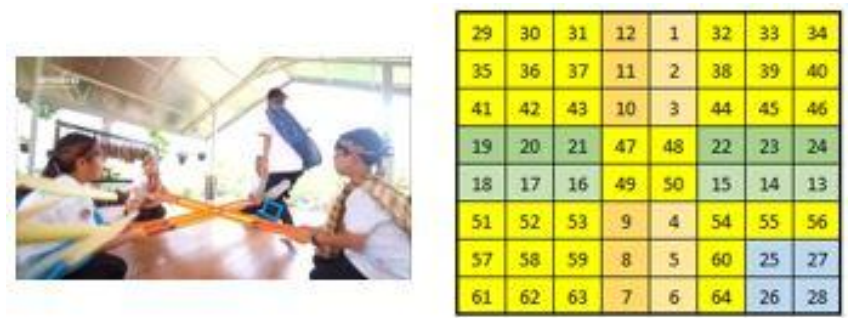

Gambar 24. Contoh Pengambilan Pola D

\begin{tabular}{|c|c|c|c|c|c|c|c|}
\hline 64 & 49 & 48 & 33 & 32 & 17 & 16 & 1 \\
\hline 63 & 50 & 47 & 34 & 31 & 18 & 15 & 2 \\
\hline 62 & 51 & 46 & 35 & 30 & 19 & 14 & 3 \\
\hline 61 & 52 & 45 & 36 & 29 & 20 & 13 & 4 \\
\hline 60 & 53 & 44 & 37 & 28 & 21 & 12 & 5 \\
\hline 59 & 54 & 43 & 38 & 27 & 22 & 11 & 6 \\
\hline 58 & 55 & 42 & 39 & 26 & 23 & 10 & 7 \\
\hline 57 & 56 & 41 & 40 & 25 & 24 & 9 & 8 \\
\hline
\end{tabular}

Gambar 24 dari permainan Rangku Alu dilihat dari atas formasi antara bambu dan penarinya digunakan untuk memasukkan ke dalam setiap blok setiap 8 bit dari karakter plainteks kedalam pola D dengan menggunakan Microsoft Excel. Kemudian pola yang sudah diberi angka tersebut mengambil data bit dari pola pemasukan plaintext sesuai Gambar 25.

Setelah pola yang terdapat di Gambar 19 dilakukan perhitungan XOR dengan pola yang terdapat di Gambar 11, begitu juga Gambar 21 dilakukan perhitungan XOR dengan 
Gambar 13, Gambar 23 dilakukan perhitungan XOR dengan Gambar 15, dan Gambar 25 dilakukan perhitungan XOR dengan Gambar 17. Serta dimana sudah disesuaikan dengan pola yang didapat dari hasil korelasi, maka proses enkripsi putaran 1 telah selesai. Kemudian dilakukan proses yang sama hingga putaran ke-10 untuk mendapatkan ciphertext akhir.

Setelah proses enkripsi selesai, langkah selanjutnya adalah masuk ke proses dekripsi. Proses dekripsi adalah proses merubah ciphertext menjadi plaintext awal. Untuk mendapatkan plaintext awal, langkah-langkahnya sama seperti proses enkripsi, namun pada proses dekripsi dimulai dari ciphertext yang kemudian dilakukan perhitungan XOR dengan pola kunci yang akan menghasilkan plaintext. Dalam proses dekripsi yang dimulai dari putaran ke-1 menuju putaran ke-10, dilakukan persis seperti dari putaran ke-10 menuju putaran ke-1 pada proses enkripsi.

Untuk pengujian menggunakan algoritma tersebut, dilakukan dengan mengambil contoh plaintext yaitu "DIESUKSW" dan kunci yaitu "BUDAYAKU". Kemudian dilakukan proses enkripsi sebanyak 10 putaran. Dimana di setiap putaran enkripsi akan mendapatkan ciphertext dan konversi ke dalam bentuk Hexa. Sehingga hasil enkripsi dari putaran ke-10 adalah final ciphertext yang ditunjukkan seperti Tabel III di bawah ini.

TABEL III

HASIL CIPHERTEXT SETIAP PUTARAN PADA PROSES ENKRIPSI

\begin{tabular}{|c|c|c|}
\hline Putaran & Hexa Input & Hexa Output \\
\hline 1 & 44494553554B5357 & B566E43493E97CF2 \\
\hline 2 & B566E43493E97CF2 & 54347A0D1A82A24A \\
\hline 3 & 54347A0D1A82A24A & B6D60FFAE9969FC3 \\
\hline 4 & B6D60FFAE9969FC3 & 202DF0651BF3E1BC \\
\hline 5 & 202DF0651BF3E1BC & 7CA4AD0B1542470B \\
\hline 6 & 7CA4AD0B1542470B & 323D7F7D0DABADD8 \\
\hline 7 & 323D7F7D0DABADD8 & 8F6D87EA59A510B1 \\
\hline 8 & 8F6D87EA59A510B1 & FA6921B5D004D82E \\
\hline 9 & FA6921B5D004D82E & 7019CBCB490870CB \\
\hline 10 & 7019CBCB490870CB & 91CA5590ED252A90 \\
\hline
\end{tabular}

Dari setiap putaran, tentunya akan menghasilkan nilai korelasi antara plaintext dengan ciphertext yang bertujuan untuk menilai seberapa acak hasil enkripsi yang berupa ciphertext dengan plaintext awal pada masing-masing putaran. Nilai korelasi itu sendiri berkisaran 1 sampai -1 dimana jika nilai korelasi mendekati 0 , maka plaintext dan ciphertext tidak memiliki nilai yang berhubungan. Akan tetapi jika nilai korelasi mendekati 1 atau -1, maka nilai dari korelasi itu sangat berhubungan.

TABEL IV

ALGORITMA ENKRIPSI DAN DEKRIPSI

\begin{tabular}{|c|l|c|l|}
\hline No & Proses Enkripsi & No & \multicolumn{2}{|c|}{ Proses Dekripsi } \\
\hline 1. & Masukkan plaintext & 1. & Masukkan ciphertext \\
\hline 2. & Plaintext diubah ke & 2. & Ciphertext diubah ke \\
\hline
\end{tabular}

\begin{tabular}{|c|c|c|c|}
\hline No & Proses Enkripsi & No & Proses Dekripsi \\
\hline & decimal & & decimal \\
\hline 3. & $\begin{array}{l}\text { Decimal diubah } \mathrm{ke} \\
\text { Binary }\end{array}$ & 3. & $\begin{array}{l}\text { Decimal diubah } \mathrm{ke} \\
\text { Binary }\end{array}$ \\
\hline 4. & $\begin{array}{l}\text { Bit Binary dimasukkan } \\
\text { ke kolom matriks } 8 \times 8 \\
\text { pada plaintext proses } \\
\text { pertama }(\mathrm{P} 1)\end{array}$ & 4. & $\begin{array}{l}\text { Bit } \text { Binary dimasukkan } \\
\text { ke kolom matriks } 8 \times 8 \\
\text { C4 dengan pola } \\
\text { pemasukan plaintext }\end{array}$ \\
\hline 5. & $\begin{array}{l}\text { Bit pada kolom matriks } \\
\text { P1 diambil } \\
\text { menggunakan pola } \mathrm{A}\end{array}$ & 5. & $\begin{array}{l}\text { C4 di-XOR dengan K4 } \\
\text { menghasilkan } \mathrm{P} 4\end{array}$ \\
\hline 6. & $\begin{array}{lr}\text { Bit } & \text { pengembalian } \\
\text { dimasukkan lagi ke } \\
\text { dalam } & \text { matriks } \\
\text { mendapatkan } & \text { hasil } \\
\text { akhir P1 } & \\
\end{array}$ & 6. & $\begin{array}{l}\text { P4 diproses dengan } \\
\text { pola } \\
\text { plaintext }\end{array}$ \\
\hline 7. & $\begin{array}{l}\text { di-XOR dengan } \mathrm{K} 1 \\
\text { enghasilkan } \mathrm{C} 1\end{array}$ & 7. & $\begin{array}{l}\text { P4 dilakukan proses S- } \\
\text { Box }\end{array}$ \\
\hline 8. & $\begin{array}{l}\text { li P3 untuk } \\
\text { njutnya }\end{array}$ & 8. & $\begin{array}{l}\text { Hasil proses P4 yang } \\
\text { telah melalui S-Box } \\
\text { dimasukkan kedalam } \\
\text { matriks } 8 x 8 \text { lagi dengan } \\
\text { pola pengambilan pola } \\
\text { D }\end{array}$ \\
\hline 9. & $\begin{array}{l}\text { Bit pada kolom matrix } \\
\text { P3 diambil } \\
\text { menggunakan pola C }\end{array}$ & 9. & $\begin{array}{l}\text { P4 menjadi C2 untuk } \\
\text { proses selanjutnya }\end{array}$ \\
\hline 10. & $\begin{array}{lr}\text { Bit r pengembalian } \\
\text { dimasukkan } & \text { lagi ke } \\
\text { dalam } & \text { matriks } \\
\text { mendapatkan } & \text { hasil } \\
\text { akhir P3 } & \\
\end{array}$ & 10. & $\begin{array}{l}\text { dengan K2 } \\
\mathrm{P} 2\end{array}$ \\
\hline 11. & $\begin{array}{l}\text { P3 di-XOR dengan K3 } \\
\text { menghasilkan } \mathrm{C} 3\end{array}$ & 11. & $\begin{array}{l}\text { P2 diproses } \text { dengan } \\
\text { polar pemasukan } \\
\text { plaintext }\end{array}$ \\
\hline 12. & $\begin{array}{l}\text { i P2 untuk } \\
\text { ajutnya }\end{array}$ & 12. & $\begin{array}{l}\text { Hasil proses } \mathrm{P} 2 \\
\text { dimasukkan ke dalam } \\
\text { matriks } 8 \times 8 \text { lagi dengan } \\
\text { pola pengambilan pola } \\
\mathrm{B}\end{array}$ \\
\hline 13. & $\begin{array}{l}\text { Bit pada kolom matriks } \\
\text { P2 diambil } \\
\text { menggunakan pola B }\end{array}$ & 13 & $\begin{array}{l}\text { P2 menjadi C3 untuk } \\
\text { proses selanjutnya }\end{array}$ \\
\hline 14. & $\begin{array}{lr}\text { Bit pengembalian } \\
\text { dimasukkan } & \text { lagi } \\
\text { kedalam } & \text { matriks } \\
\text { mendapatkan } & \text { hasil } \\
\text { akhir P2 } & \\
\end{array}$ & 14 & $\begin{array}{l}\text { C3 di-XOR dengan K3 } \\
\text { menghasilkan } \mathrm{P} 3\end{array}$ \\
\hline 15. & $\begin{array}{l}\mathrm{P} 2 \text { di-XOR dengan } \mathrm{K} 2 \\
\text { menghasilkan } \mathrm{C} 2\end{array}$ & 15 & $\begin{array}{l}\text { P3 diproses dengan } \\
\text { pola } \\
\text { plaintext }\end{array}$ \\
\hline 16. & $\begin{array}{l}\text { di P4 untuk } \\
\text { injutnya }\end{array}$ & 16 & $\begin{array}{l}\text { Hasil proses P3 } \\
\text { dimasukkan kedalam } \\
\text { matriks } 8 \times 8 \text { lagi dengan } \\
\text { pola pengambilan pola } \\
\text { C }\end{array}$ \\
\hline 17. & $\begin{array}{l}\text { Bit pada kolom matriks } \\
\text { P4 diambil } \\
\text { menggunakan pola D }\end{array}$ & 17 & $\begin{array}{l}\text { P3 menjadi C1 untuk } \\
\text { proses selanjutnya }\end{array}$ \\
\hline 18 & $\begin{array}{l}\text { Bit yang telah diambil } \\
\text { kemudian diubah ke }\end{array}$ & 18 & $\begin{array}{l}\mathrm{C} 1 \text { di-XOR dengan } \mathrm{K} 1 \\
\text { menghasilkan } \mathrm{P} 1\end{array}$ \\
\hline
\end{tabular}




\begin{tabular}{|c|c|c|c|}
\hline No & Proses Enkripsi & No & Proses Dekripsi \\
\hline & Decimal & & \\
\hline 19. & $\begin{array}{l}\text { Decimal diubah ke } \\
\text { Hexa }\end{array}$ & 19. & $\begin{array}{l}\text { P1 diproses dengan } \\
\text { pola } \\
\text { plaintext }\end{array}$ \\
\hline 20. & $\begin{array}{l}\text { Hasil Hexa dilakukan } \\
\text { proses S-Box dan } \\
\text { menghasilkan } \\
\text { yang berbeda. }\end{array}$ & 20. & $\begin{array}{l}\text { Hasil proses P1 } \\
\text { dimasukkan kedalam } \\
\text { matriks } 8 \times 8 \text { lagi dengan } \\
\text { pola pengambilan pola } \\
\mathrm{B}\end{array}$ \\
\hline 21. & $\begin{array}{llr}\text { Hexa } & \text { yang } & \text { telah } \\
\text { melalui proses } & \text { S-Box } \\
\text { diubah } & \text { menjadi } & \text { Binary. } \\
\end{array}$ & 21 & $\begin{array}{l}\text { Kemudian diambil bit } \\
\text { dari P1 dan dipindah ke } \\
\text { tabel Binary }\end{array}$ \\
\hline 22. & $\begin{array}{lr}\text { Bunary diubah ke Bit, } \\
\text { Bit dimasukkan lagi ke } \\
\text { dalam } & \text { matriks } \\
\text { mendapatkan } & \text { hasil } \\
\text { akhir P4 } & \\
\end{array}$ & 22, & $\begin{array}{l}\text { didapatkan } \\
\text { ecimal }\end{array}$ \\
\hline 23. & $\begin{array}{l}\text { XOR dengan K4 } \\
\text { asilkan C4 }\end{array}$ & 23. & $\begin{array}{l}\text { Decimal diubah ke } \\
\text { Hexa }\end{array}$ \\
\hline 24. & C4 diubah ke Decimal & 24 & Hexa diubah ke Char \\
\hline 25. & $\begin{array}{l}\text { Decimal diubah ke } \\
\text { Char untuk } \\
\text { mendapatkan } \\
\text { ciphertext } \text { akhir. }\end{array}$ & 25. & $\begin{array}{l}\text { Char digabungkan dan } \\
\text { menjadi hasil plaintext }\end{array}$ \\
\hline
\end{tabular}

Tabel IV merupakan algoritma proses enkripsi dan dekripsi secara menyeluruh. Proses enkripsi menghasilkan chipertext akhir, dan proses dekripsi menghasilkan plaintext awal.

Algoritma proses Kunci (key), dijelaskan sebagai berikut:

1. Masukkan Kunci

2. Kunci diubah ke Decimal

3. Decimal ke Binary

4. Bit Binary dimasukkan ke kolom K1 dengan pola pemasukan Kunci

5. Bit kunci diambil dengan pola pengambilan Kunci

6. Binary hasil pengambilan dimasukkan ke dalam kolom matriks K1

7. $\mathrm{K} 1=\mathrm{K} 3$

8. $\mathrm{K} 3$ dimasukkan ke kolom matriks $\mathrm{K} 3$ dengan pola pemasukan

9. Bit kunci diambil dengan pola pengambilan Kunci

10. Binary hasil pengambilan dimasukkan ke dalam kolom matriks K3

11. $\mathrm{K} 3=\mathrm{K} 2$

12. $\mathrm{K} 2$ dimasukkan ke kolom matriks $\mathrm{K} 2$ dengan pola pemasukan

13. Bit kunci diambil dengan pola pengambilan Kunci

14. Binary hasil pengambilan dimasukkan ke dalam kolom matriks $\mathrm{K} 2$

15. $\mathrm{K} 2=\mathrm{K} 4$

16. $\mathrm{K} 4$ dimasukkan ke kolom matriks $\mathrm{K} 4$ dengan pola pemasukan

17. Bit kunci diambil dengan pola pengambilan Kunci

18. Binary hasil pengambilan dimasukkan ke dalam kolom matriks K4
TABEL V

PSEUDO CODE PROSES ENKRIPSI DAN DEKRIPSI

\begin{tabular}{l|}
\hline Proses Enkripsi \\
$\begin{array}{l}\text { Program ini digunakan untuk } \\
\text { melakukan proses enkripsi data }\end{array}$ \\
64 bit $\}$
\end{tabular}

Proses Dekripsi
$\{$ Program ini digunakan
untuk melakukan proses
dekripsi data 64 bit $\}$

Kamus

$\mathrm{P}, \mathrm{K}, \mathrm{P} 1, \mathrm{~K} 1, \mathrm{P} 2, \mathrm{~K} 2, \mathrm{P} 3, \mathrm{~K} 3, \mathrm{P} 4, \mathrm{~K} 4$, = integer

$\mathrm{C}, \mathrm{C} 1, \mathrm{C} 2, \mathrm{C} 3, \mathrm{C} 4=$ integer

\begin{tabular}{l|l}
\hline Start & Start \\
$\mathrm{C} 1<-\mathrm{P} 1 \oplus \mathrm{K} 1$ & $\mathrm{P} 4<-$
\end{tabular}

$\mathrm{C} 1<-\mathrm{P} 1 \oplus \mathrm{K} 1$

Input $\mathrm{P}$

Read $\mathrm{P}$

$\mathrm{P}$ to ASCII

ASCII to Binary

Dari Binary $=$ blok matriks $P$, masukkan Binary

P menggunakan Pola pemasukan awal

Dari blok matriks $\mathrm{P}=$

Binary, ambil bit

$\mathrm{P}$ dengan Pola Permainan

Tradisional Rangku Alu

Plaintext 1 = blok matriks P1

Output P1

Input $\mathrm{K}$

\section{Read $\mathrm{K}$}

$\mathrm{K}$ to ASCII

ASCII to Binary

Dari Binary $=$ blok matriks K, masukkan Binary

K menggunakan Pola pemasukan awal

Dari blok matriks $\mathrm{K}=$ Binary, ambil bit

$\mathrm{K}$ dengan Pola Kunci 1 Output $\mathrm{K} 1$

= blok matriks $\mathrm{K}$

Print $\mathrm{C} 1$

$\mathrm{C} 3<-\mathrm{P} 3 \oplus \mathrm{K} 3$

Input $\mathrm{P}$

Read $\mathrm{P}$

$\mathrm{P}$ to ASCII

ASCII to Binary

Dari Binary $=$ blok matriks P,

masukkan Binary

P menggunakan Pola

pemasukan awal

Dari blok matriks $\mathrm{P}=$

Binary, ambil bit

P dengan Pola Permainan

Tradisional Rangku Alu

Plaintext $3=$ blok matriks P3

Output P3

Input $\mathrm{K}$

Read K

$\mathrm{K}$ to ASCII

ASCII to Binary
$\mathrm{P} 4<-\mathrm{C} 4 \oplus \mathrm{K} 4$
Input $\mathrm{C} 4$
Read $\mathrm{C} 4$

C4 to ASCII

ASCII to Binary

Dari Binary = blok matriks C4, masukan Binary

Input $\mathrm{K}$

Read $\mathrm{K}$

K to ASCII

ASCII to Binary

Dari Binary = blok matriks $\mathrm{K}$, masukkan

Binary

K menggunakan Pola pemasukan awal

Dari blok matriks $\mathrm{K}$

$=$ BINER, ambil bit

$K$ dengan Pola Kunci

4 = blok matriks K4

Output K4

$\mathrm{C} 4 \oplus \mathrm{K} 4$

Output $\mathrm{P} 4$

Dari kolom matrik $\mathrm{P} 4=$

Binary, ambil bit $\mathrm{P} 4$

Binary to HEXA

Dari HEXA = Tabel $S$ -

HEXA ditranformasi menggunakan $S$-Box

Dari Binary $\mathrm{P} 4=$

kolom matrik $\mathrm{P} 4$,

masukan Binary

menggunakan pola pengambilan 4

Print $\mathrm{P} 4$

$\mathrm{P} 2<-\mathrm{C} 2 \oplus \mathrm{K} 2$

Input $\mathrm{C} 2$

Read $\mathrm{C} 2$

C2 to ASCII

ASCII to Binary

Dari Binary $=$ blok

matrik C2, masukan Binary

Input $\mathrm{K}$

Read K

K to ASCII

ASCII to Binary

Dari Binary = blok matriks $\mathrm{K}$, masukkan
Box, masukan HEXA 


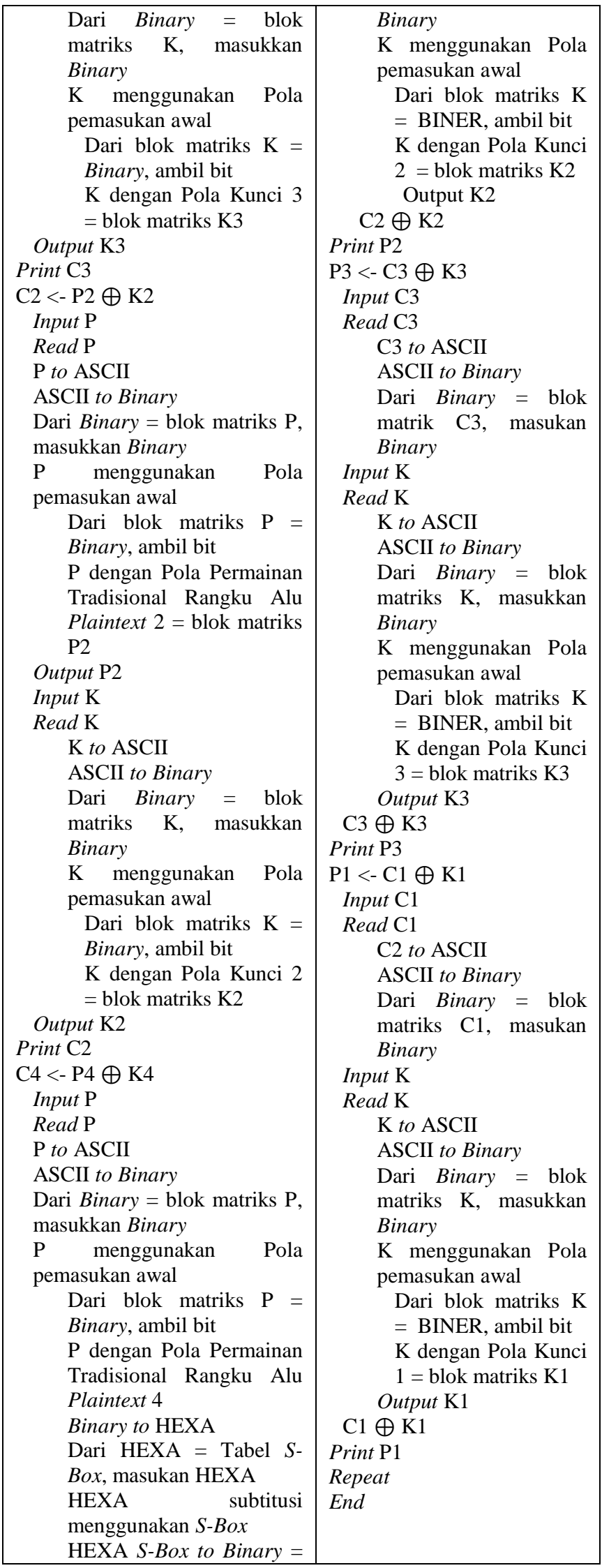

\begin{tabular}{|l|}
\hline blok matriks $\mathrm{P} 4$ \\
Output $\mathrm{P} 1$ \\
Input $\mathrm{K}$ \\
Read $\mathrm{K}$ \\
$\mathrm{K}$ to ASCII \\
ASCII to Binary $\quad$ blok \\
Dari Binary $=$ \\
matriks K, masukkan \\
Binary $\mathrm{K}$ menggunakan Pola \\
pemasukan awal \\
Dari blok matriks $\mathrm{K}=$ \\
Binary, ambil bit \\
$\mathrm{K}$ dengan Pola Kunci 4 \\
$=$ blok matriks K4 \\
Output $\mathrm{K} 4$ \\
Print $\mathrm{C} 4$ \\
Repeat \\
End
\end{tabular}

Tabel V merupakan hasil dari proses S-Box yang dilakukan pada setiap putaran untuk proses plaintext 4. Proses S-Box dilakukan agar ciphertext yang dihasilkan pada setiap akhir putaran menjadi lebih acak.

TABEL VI

NILAI KORELASI SETIAP PUTARAN

\begin{tabular}{|c|c|}
\hline Putaran & Nilai Korelasi \\
\hline 1 & -0.225539242 \\
\hline 2 & -0.284325633 \\
\hline 3 & 0.554163168 \\
\hline 4 & 0.04234029 \\
\hline 5 & -0.881122619 \\
\hline 6 & 0.320165878 \\
\hline 7 & -0.025066312 \\
\hline 8 & 0.130136634 \\
\hline 9 & 0.222855921 \\
\hline 10 & 0.18079767 \\
\hline
\end{tabular}

Tabel VI menunjukkan nilai korelasi pada setiap putaran dan dapat disimpulkan bahwa algoritma Kriptografi Block Cipher berbasis pola permainan tradisional Rangku Alu memiliki korelasi yang lemah (mendekati 0) dan menghasilkan nilai korelasi yang acak (korelasi bernilai 1 hingga -1 , dan sangat lemah jika mendakati 0). Kemudian pengujian Avalanche Effect dilakukan agar dapat mengetahui nilai perubahan bit yang ada ketika plaintext diubah. Pengujian dilakukan dengan mengubah karakter yang terdapat pada plaintext awal, dan tentunya akan menghasilkan perbedaan pada setiap putarannya.

Pada umumnya, bit pada chipertext akan mengalami perubahan dari jumlah bit pada plaintext sebesar $50 \%$. Suatu Avalanche Effect dikatakan baik jika perubahan bit yang dihasilkan berkisar antara 45\% - 60\% (sekitar separuhnya) [12]. 


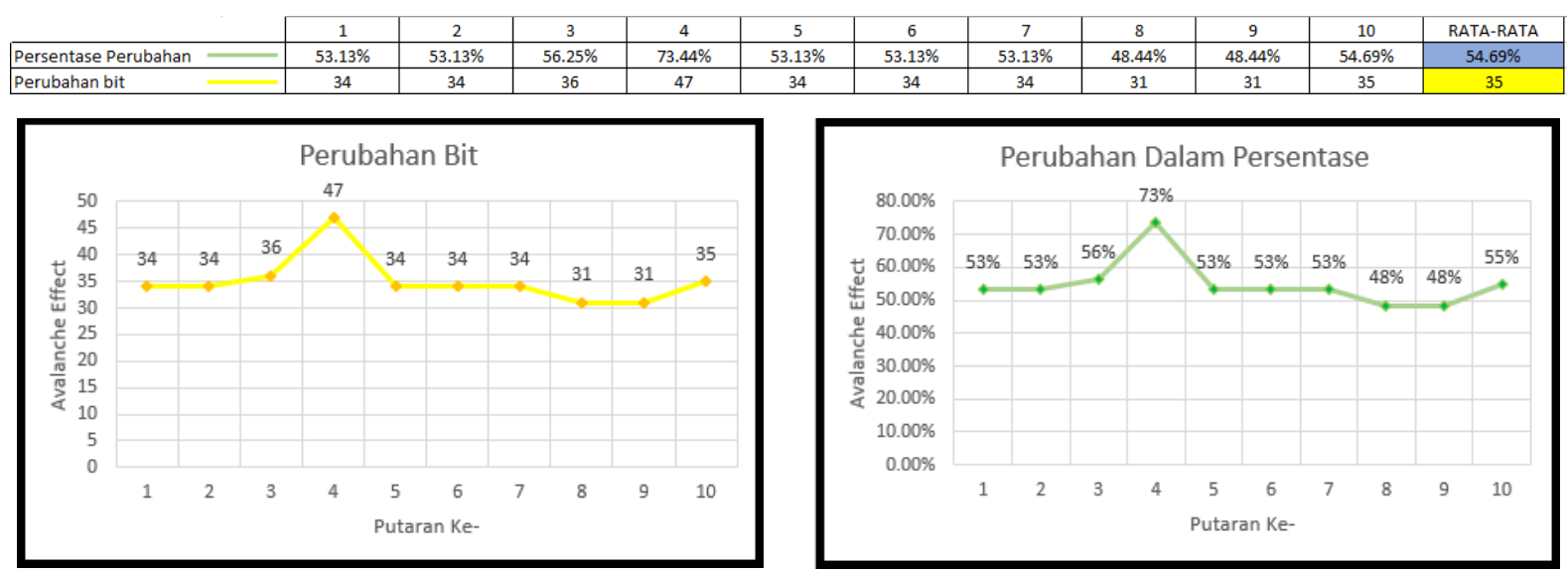

Gambar 26. Grafik Avalanche Effect dari Plaintext "DIESUKSW"

Gambar 26 adalah hasil dari pengujian Avalanche Effect dimana plaintext awal yang digunakan adalah "DIESUKSW". Pada putaran keempat perubahan bit yang tejadi cukup besar yaitu 73,44\%. Dengan ini berarti terdapat perubahan bit yang baik, namun untuk nilai Avalanche Effect dapat dikatakan tidak begitu baik karena jauh dari angka 50\%. Berdasarkan hasil putaran pertama hingga putaran ke sepuluh, dapat disimpulkan bahwa rata-rata hasil pengujian Avalanche Effect ini yaitu sebesar 54,69\% yang berarti termasuk kategori sangat baik.

\begin{tabular}{|l|c|c|c|c|c|c|c|c|c|c|c|}
\multicolumn{1}{c|}{} & 1 & 2 & 3 & 4 & 5 & 6 & 7 & 8 & 9 & 10 & RATA-RATA \\
\hline Persentase Perubahan & $48.44 \%$ & $46.88 \%$ & $43.75 \%$ & $56.25 \%$ & $48.44 \%$ & $51.56 \%$ & $51.56 \%$ & $53.13 \%$ & $46.88 \%$ & $46.88 \%$ & $49.38 \%$ \\
\hline Perubahan bit & 31 & 30 & 28 & 36 & 31 & 33 & 33 & 34 & 30 & 30 & 31.6 \\
\hline
\end{tabular}
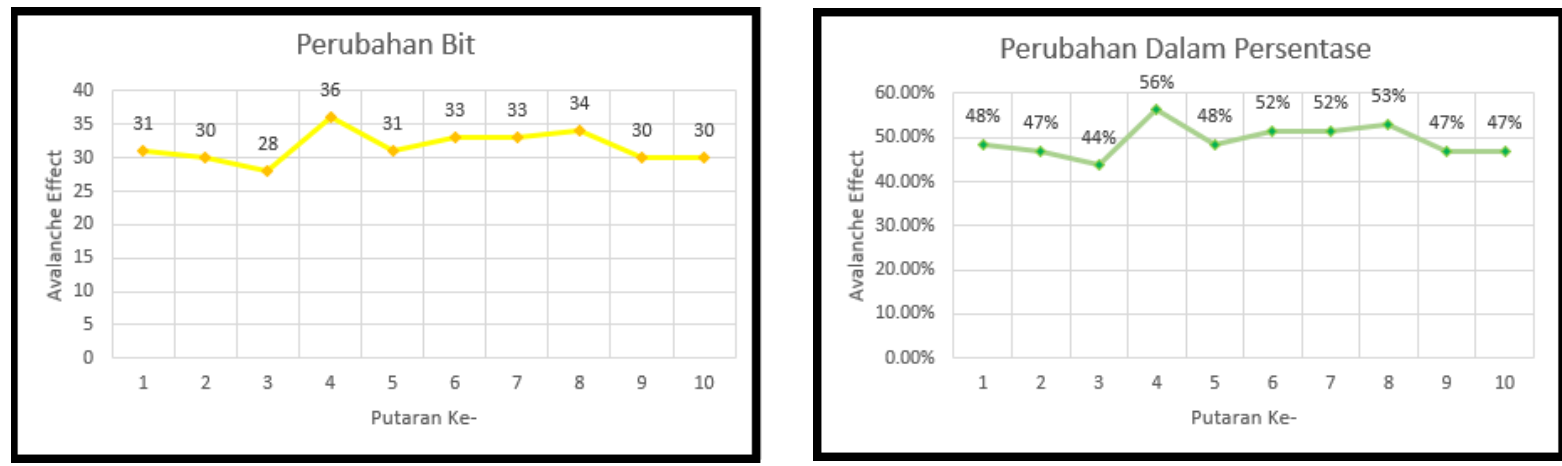

Gambar 27. Grafik Avalanche Effect dari Plaintext "PERDANA1"

Pada Gambar 27 yang merupakan hasil dari pengujian Avalanche Effect dari plaintext awal "PERDANA1", menghasilkan perubahan bit yang tidak terlalu tinggi dimana paling tingi hanya mencapai $56 \%$ pada putaran keempat. Nilai Avalanche Effect yang dihasilkan dari plaintext awal "PERDANA1" lebih baik dibandingkan dengan plaintext awal "DIESUKSW" yaitu sebesar 49,38\% dengan kategori sangat baik.

\section{KESIMPULAN}

Enkripsi Block Cipher memiliki kelemahan mudahnya pendeteksian terutama jika ada blok-blok data yang sama di enkripsi manggunakan kunci yang sama, maka akan menghasilkan cipherteks yang sama. Kunci dalam dunia kriptografi merupakan data yang bersifat private, sekali data kunci telah di ketahui seorang kriptoanalis juga perlu melakukan analisa berkaitan dengan ukuran blok (dalam penelitian ini menggunakan 64 bit), alur pola yang digunakan (nilai korelasi 0,011), metode untuk meningkatkan keacakan (menambahkan metode XOR), serta berapa putaran yang digunakan (menggunakan total 20 putaran). Kemudian berdasarkan penelitian yang dilakukan, dapat disimpulkan bahwa Kriptografi Block Cipher 64 bit berbasis pola permainan tradisional Rangku Alu ini menghasilkan output yang acak sehingga dapat digunakan sebagai alternatif dalam pengamanan data. Dalam pengujian Avalanche Effect yang dilakukan, menunjukkan bahwa proses enkripsi di setiap putaran memiliki perubahan yang mencapai $49,38 \%$ yang berarti masuk ke dalam kategori yang sangat baik. 


\section{DAFTAR PUSTAKA}

[1] Tuhumury, Frellian dkk, "Perancangan Kriptografi Block Cipher 256 Bit Berbasis pada Pola Tuangan Air", Universitas Kristen Satya Wacana, 2016.

[2] Nanang Ajim, "Permainan Tradisional Rangku Alu", [Online]. Available: http://www.mikirbae.com/2016/05/permainan-tradisionalrangku-alu.html. [Accessed 12 April 2019].

[3] Humaira, Rafiqa, dkk, "Kriptanalisis dengan Metode Brute Force pada Graphics Processing Unit", Hal. 2-5, Bandung, 2015.

[4] F. D. Paliama, "Perancangan Kriptografi Block Cipher Berbasis Pada Teknik Formasi Permainan Bola Perancangan Kriptografi Block Cipher Berbasis Pada Teknik Formasi Permainan Bola," Universitas Kristen Satya Wacana, 2016.

[5] N. M. Louhenapessy, "Perancangan Kriptografi Block Cipher Berbasis Pola Formasi Futsal 1-2-1," Universitas Kristen Satya Wacana, 2016.

[6] B. L. Setiyadi, "Perancangan Kriptografi Block Cipher Berbasis Pada Pola Gerakan Lempeng Tektonik Divergensi dan Konvergensi Program Studi Teknik Informatika Fakultas Teknologi Informasi
Universitas Kristen Satya Wacana Salatiga November 2016 Perancangan Kriptografi Block Cipher," Universitas Kristen Satya Wacana, 2016.

[7] Guntoro, "Perancangan Kriptografi Block Cipher Berbasis Pola Ikan Berenang," Universitas Kristen Satya Wacana, 2016.

[8] K. D. Cahyono, "Perancangan Kriptografi Block Cipher dengan Langkah Permainan Engklek," Universitas Kristen Satya Wacana, 2016.

[9] Munir, R., "Kriptografi", Informatika, Bandung, 2006.

[10] A. J. Leodrian, "Pengaruh Perubahan Ciphertext Terhadap Perancangan Kriptografi Block Cipher 64 Bit Berbasis Pola Ikatan Jimbe Dengan Menggunakan Kombinasi S-Box," Universitas Kristen Satya Wacana, 2016.

[11] Sugiyono, "Metode Penelitian Bisnis (Pendekatan Kuantitatif, Kualitatif, dan R\&D)", Alfabeta, Bandung, 2009.

[12] Sugiyanto and R. K. Hapsari, "Pengembangan Algoritma Advanced Encryption Standard pada Sistem Keamanan SMS Berbasis Android Menggunakan Algoritma Vigenere," Institut Teknologi Adhi Tama Surabaya, 2016. 